\title{
Erosion risk assessment for prioritization of conservation measures in Geleda watershed, Blue Nile basin, Ethiopia
}

\author{
Temesgen Gashaw ${ }^{1,3^{*}} \mathbb{0}$, Taffa Tulu² and Mekuria Argaw ${ }^{1}$
}

\begin{abstract}
Background: Soil erosion is among the most challenging and continuous environmental problems in the highlands of Ethiopia. This study was conducted in the Geleda watershed of the Blue Nile basin in the northwestern highlands of Ethiopia to measure erosion rates and map out erosion risks for prioritization of conservation measures. The Revised Universal Soil Loss Equation model, which was adapted to the Ethiopian conditions, was used for this purpose.

Results: Soil losses ranged from 0 in plain areas to $237 \mathrm{t} \mathrm{ha}^{-1}$ year $^{-1}$ in the steep slope areas of the watershed with an average soil loss of $23.7 \mathrm{t} \mathrm{ha}^{-1}$ year $^{-1}$. About $21.25 \%$ of the watershed area experienced soil losses above the tolerable limit of $11 \mathrm{t} \mathrm{ha}^{-1}$ year $^{-1}$. The total annual soil loss from the entire watershed area of 25,609 ha was about 157,022 tones.

Conclusions: In the steep slope areas of the watershed, where the extension of cultivated land resulted in high soil losses, soil erosion is a serious problem and requires appropriate intervention with soil conservation measures.
\end{abstract}

Keywords: Erosion risk, RUSLE, Prioritization, Conservation

\section{Background}

Soil is the basic resource for economic development and for maintaining sustainable productive landscapes and people's livelihoods especially for countries with agrarian economy like Ethiopia. However, soil degradation is a serious threat in agro-ecosystems and one of the global environmental problems (Oldeman et al. 1995; Angima et al. 2003; Blanco-Canqui and Lal 2008; Abate 2011). Globally, one-third of agricultural soils were reported as being affected by soil degradation (Hurni 2002), of which water and wind erosion account 56 and $28 \%$ of the observed damage, respectively (Blanco-Canqui and Lal 2008). Obviously, soil erosion by water is the most serious form of soil degradation and this problem is most significant in the tropics and sub-tropics compared to the rest of the regions on the Globe (Eaton 1996; Lal 2001). In Africa and Asia, soil erosion is severe, driven by high

\footnotetext{
*Correspondence: gtemesgen114@gmail.com

${ }^{1}$ Center for Environmental Science, College of Natural Sciences,

Addis Ababa University, Addis Ababa, Ethiopia
}

Full list of author information is available at the end of the article population pressure, land shortage and critical lack of resources for conservation by subsistence smallholderpoor farmers (Blanco-Canqui and Lal 2008).

Soil erosion by water has been a challenging and continuous problem in Ethiopia for decades (Hurni 1988; Gete 2000; Bewket and Teferi 2009; Kebede et al. 2015). The average annual soil loss in Ethiopia is estimated to be $18 \mathrm{t} \mathrm{ha}^{-1}$ year $^{-1}$ (Hurni 1985). The problem, however, is severe in the Ethiopian highlands (FAO 1986; Gete 2000; Reusing et al. 2000; Nyssen et al. 2004; Bewket and Teferi 2009; Abate 2011). In the Ethiopian highlands, soil erosion ranges from $16-300 \mathrm{t} \mathrm{ha}^{-1}$ year $^{-1}$ in cultivated lands (Hurni 1988). In the past, Gete (2000) also reported 130-170 $\mathrm{t} \mathrm{ha}^{-1}$ year $^{-1}$ soil loss on a similar land use in the northwestern highlands of Ethiopia. In earlier estimates, the average soil loss on cultivated croplands in the Ethiopian highlands was $42 \mathrm{t} \mathrm{ha}^{-1}$ year $^{-1}$ (Hurni 1993) and $35 \mathrm{t} \mathrm{ha}^{-1}$ year $^{-1}$ for all lands (FAO 1986). However, the acceptable soil loss that can maintain an economic and a high level of production (Wischmeier and Smith 1978; FAO 1986; Gebreyesus and Kirubel 2009) ranges 
from 5 to $11 \mathrm{t} \mathrm{ha}^{-1}$ year $^{-1}$ (Renard et al. 1996). Every year, an estimated 1.9-3.5 billion tons of topsoil in Ethiopian highlands has been lost and as a result about 20,00030,000 ha of cropland was taken out of production due to severe soil erosion in the earlier decades (EFAP 1993). Taddese (2001) also indicated that 1.5 million tons of soil has been lost in the Ethiopian highlands each year, which also has resulted in a significant loss of grain from the country's annual harvest. Estimate through modeling work also suggests that soil erosion in Ethiopia will reduce the potential production of the land by $10 \%$ in 2010 and by $30 \%$ in 2030 . As a result, the value added per capita per annum in the agricultural sector go down from US\$372 in 2010 to US\$162 in 2030 (Sonneveld and Keyzer 2003). These clearly show soil erosion is a serious problem in the highlands. As a result of soil erosion, poverty and food insecurity are concentrated in rural areas (MoARD 2010).Thus, in order to achieve food security, poverty reduction and environmental sustainability in the country reversing soil erosion is a high priority (Bewket and Teferi 2009; Abate 2011).

In order to reverse soil erosion, several efforts have been exerted since the 1970s (Bekele and Holden 1998; Menale et al. 2009; Nigussie et al. 2012). However, past soil conservation efforts did not bring significant changes to the ongoing soil degradation problems (Bekele and Holden 1998; Menale et al. 2009). Most recently, watershed management is an approach followed by the government of Ethiopia to protect soil from erosion in particular and to reverse land degradation in general (Desta et al. 2005; Gete 2006; Nigussie et al. 2012). Although dramatic reduction has been made in arresting soil erosion (AgWater Solutions 2012; Nigussie et al. 2012; Tongul and Hobson 2013), the approach has not been supported with intervention prioritizing techniques that identify highly susceptible areas using geospatial analysis. The Geleda watershed is in the northwestern of the Ethiopian highlands where soil erosion is rampant. Hence, identifying and prioritizing erosion susceptible areas for soil conservation measures are quite essential. There are barely similar efforts in the past approaches to identify and prioritize erosion risk prone areas for intervention. Therefore, the objective of this study is to analyze erosion risks across the landscape for prioritization of conservation measures in the study watershed. The limitation of this study was the soil loss estimated with the model was not validated, basically due to the absence of measured soil loss data in the studied watershed.

\section{Methods}

\section{Study area}

The Geleda watershed is found in the Blue Nile basin and geographically located between $11^{\circ} 34^{\prime}-11^{\circ} 51^{\prime} \mathrm{N}$ latitude and $37^{\circ} 26^{\prime}-37^{\circ} 42^{\prime} \mathrm{E}$ longitude (Fig. 1). The topography is hilly and elevation ranges from 1791 to $2472 \mathrm{~m}$ a.s.l. The agro-climate is largely sub-tropical (98\%), which is locally known as Weyna Dega. Agriculture is the main economic activity, which provides more than $96 \%$ of the income for the population. Based on a dataset from four meteorological stations for the period from 2007 to 2015 (Table 1), the mean annual rainfall in the study region varied between $1024 \mathrm{~mm}$ in Arb Gebeya and $1759 \mathrm{~mm}$ in Ambesame with high variability between years (Fig. 2).

\section{Determining RUSLE factor values}

The Revised Universal Soil Loss Equation (RUSLE) is an empirical soil erosion model designed to estimate the long term annual average soil loss carried by runoff from specific field slopes in specified cropping and management systems (Renard et al. 1996, 1997). RUSLE has been modified from the Universal Soil Loss Equation (USLE) by adapting the input factors to the local conditions (McCool et al. 1995; Renard et al. 1996). The RUSLE has been widely adapted and used to estimate soil loss from watersheds having different or similar land uses elsewhere (Angima et al. 2003 in Kenya; Terranova et al. 2009 in Italy; Prasannakumar et al. 2012 in India; Alexakis et al. 2013 in Cyprus; Alkharabsheh et al. 2013 in Jordan; Gelagay and Minale 2016 in Ethiopia). The model has been popularly used because of its clear and relatively simple computational inputs requirement compared to other conceptual and process based models. RUSLE estimates soil loss from sheet and rill erosion as a function of five independent factors (Wischmeier and Smith 1978) as indicated in Eq. 1 below:

$$
A=R * K * L S * C * P
$$

where $A$ is amount of soil loss in $\mathrm{t} \mathrm{ha}^{-1}$ year $^{-1}, R$ is rainfall erosivity factor, $K$ is Soil erodibility factor, $L S$ is slope length and steepness factor, $C$ is cropping and land-cover factor, and $P$ is the conservation practice factor.

The input factors for the RUSLE model in this study were adapted to Ethiopian conditions by Hurni (1985) and Hellden (1987).

\section{Rainfall erosivity (R) factor}

The R-factor represents the erosive force of a specific rainfall event (Wischmeier and Smith 1978; Alexakis et al. 2013). It is actually determined by the amount, intensity and distribution of rainfall (Tadesse and Abebe 2014). USLE and its revised version RUSLE in their original equation require rainfall intensity data (Wischmeier and Smith 1978; Bewket and Teferi 2009). Due to the absence of rainfall intensity data, we adopted the R-correlation established by Hurni (1985) for Ethiopia (Eq. 2), which was used in other similar studies (Bewket and Teferi 2009; Abate 


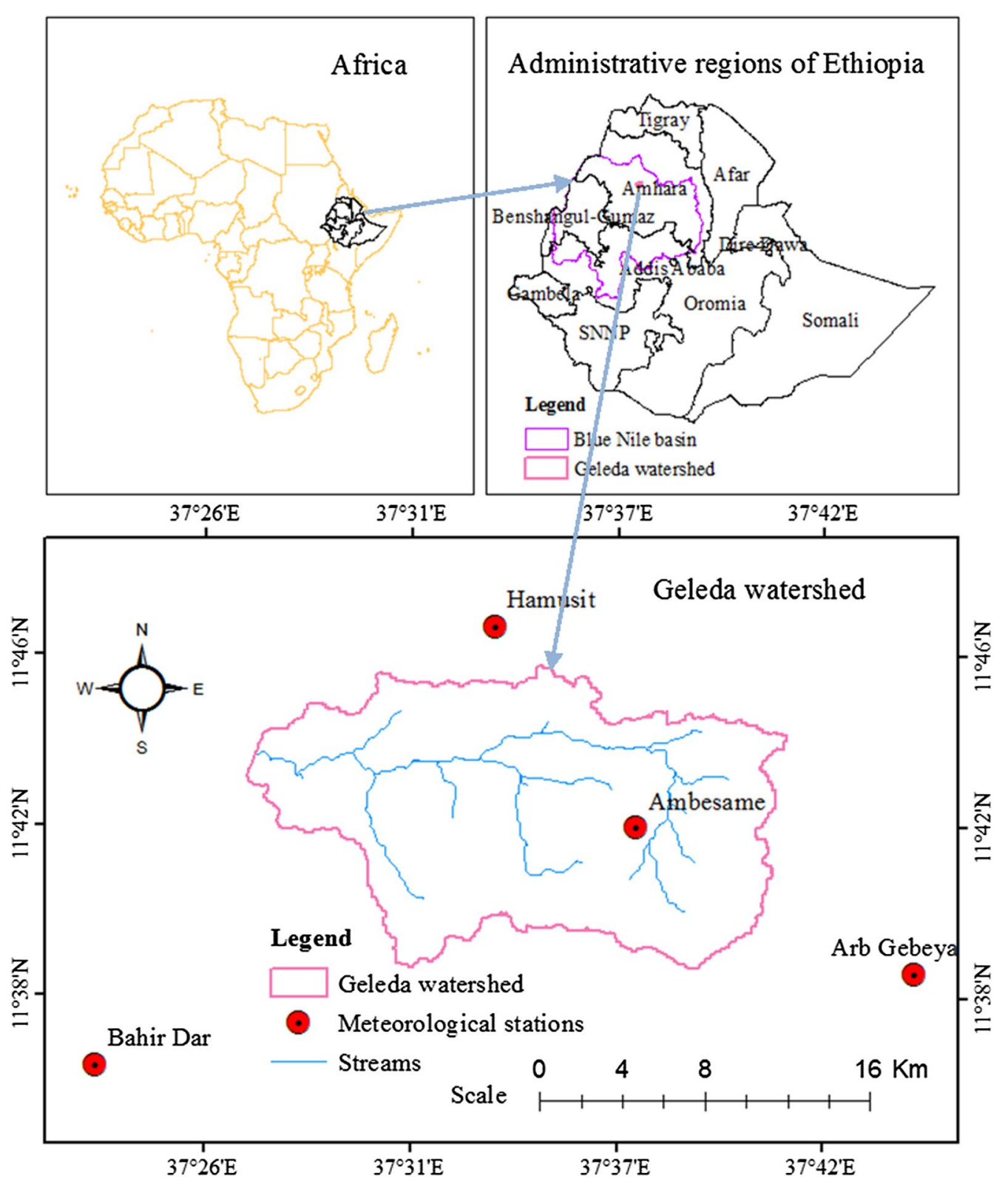

Fig. 1 Location map of the Geleda watershed in the Blue Nile basin in Ethiopia

Table 1 Mean annual rainfall and R-factors of the four meteorological stations in the Geleda watershed

\begin{tabular}{|c|c|c|c|c|}
\hline \multirow[t]{2}{*}{ Stations } & \multicolumn{2}{|l|}{ Location } & \multirow{2}{*}{$\begin{array}{l}\text { Mean annual rainfall } \\
(\mathrm{mm}) \\
(2007-2015)\end{array}$} & \multirow[t]{2}{*}{ R-factor } \\
\hline & Latitude & Longitude & & \\
\hline Arb Gebeya & 11.636 & 37.749 & 1024.33 & 567.55 \\
\hline Ambesame & 11.69982 & 37.62485 & 1758.63 & 980.23 \\
\hline Hamusit & 11.788 & 37.562 & 1728.92 & 963.53 \\
\hline Bahir Dar & 11.595 & 37.385 & 1316.34 & 731.66 \\
\hline
\end{tabular}

2011; Derege et al. 2012; Tadesse and Abebe 2014; Kebede et al. 2015; Gelagay and Minale 2016). We calculated the mean annual rainfall based on monthly rainfall data of four meteorological stations (Table 1) for the period 2007-2015 and computed the R-factor for each meteorological station using the following equation (Hurni 1985):

$$
R=-8.12+(0.562 \times P)
$$

where $R$ is the rainfall erosivity factor and $P$ is the mean annual rainfall (mm). 


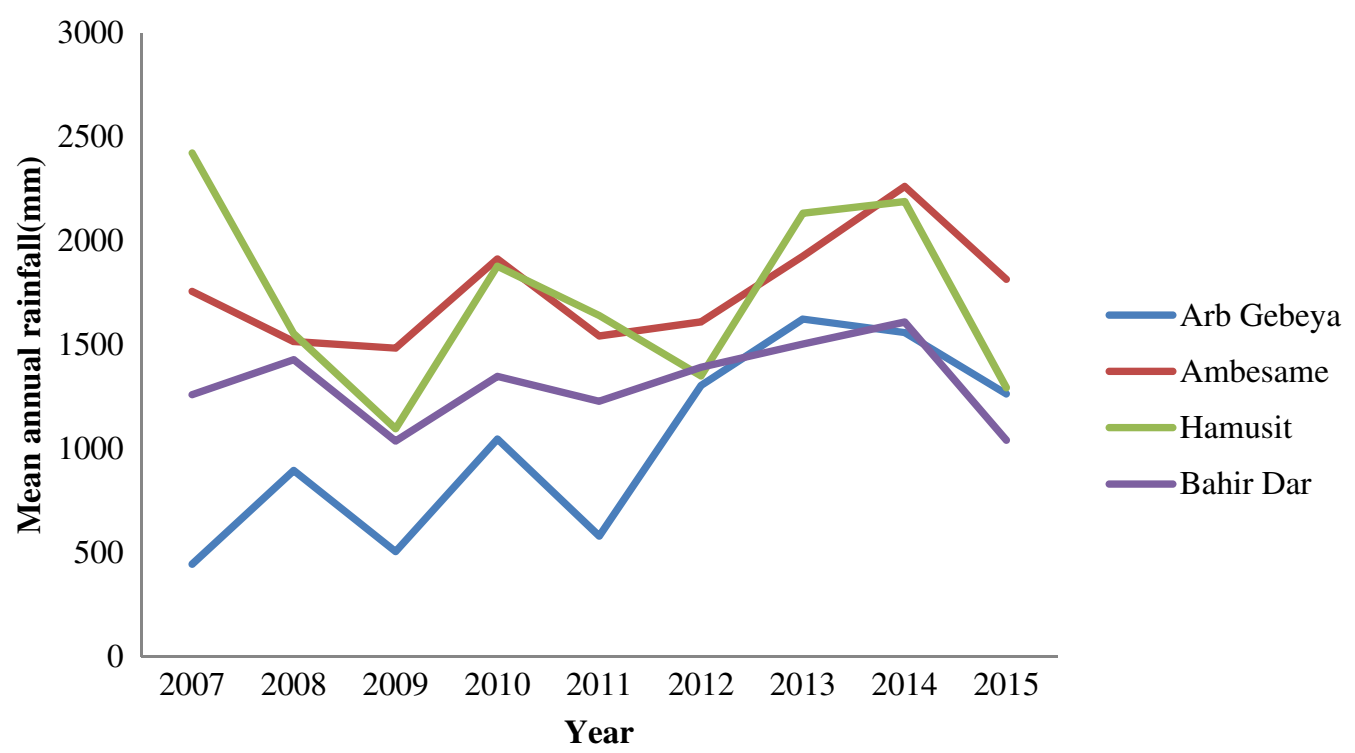

Fig. 2 Mean annual rainfall of the four weather stations in the Geleda watershed for the period from 2007 to 2015

To produce a $\mathrm{R}$-factor map, the interpolated $\mathrm{R}$-factors were converted into a raster format with $30 \mathrm{~m}$ resolution and extracted for the studied watershed area (Fig. 3).

\section{Soil erodibility (K) factor}

The K-factor accounts the influence of soil properties on soil loss during storm events on upland areas (Wischmeier and Smith 1978; Renard et al. 1996). Few soil properties, which affect soil erodibility, include soil texture, drainage condition, soil depth, structural integrity and organic content (Gebreyesus and Kirubel 2009; Prasannakumar et al. 2012). There are various methods of determining the K-factor. Among the most commonly used methods, the soil nomograph uses relative proportions of soil texture, permeability, soil structure and organic matter content (Wischmeier and Smith 1978; Abate 2011; Hailu and Klik 2015; Kebede et al. 2015). Since determining theses parameters from the soil map is practically difficult (Derege et al. 2012), the K-factor for this study was drawn from Hurni (1985), Hellden (1987) and the Soil Conservation Research Project (1996), which adapted the K-factor based on soil color and soil types to Ethiopia. Similar studies conducted in different parts of the country applied the adapted soil erodibility values (Bewket and Teferi 2009; Derege et al. 2012; Tadesse and Abebe 2014). Thus, the K-factor values for the studied watershed were determined based on the soil color, which were dominated by red with $\mathrm{K}$ value of 0.25 and brown with $\mathrm{K}$ value of 0.2 . A soil map of the watershed, which was obtained from Amhara National Regional
State Bureau of Finance and Economic Development, was used to map the K-factor values (Table 2) and later the resulting vector map was converted into a raster map showing the soil erodibility of the watershed with a cell size of $30 \mathrm{~m}$ (Fig. 4).

\section{Topographic (LS) factor}

The LS-factor in RUSLE is a combination of slope length (L) and slope steepness (S) factors (Wischmeier and Smith 1978; Moore and Wilson 1992; McCool et al. 1995; Prasannakumar et al. 2012; Alexakis et al. 2013). The LS-factor is considered in the soil loss equation model due to the fact that both the length and the steepness of the slope substantially affect the rate of soil erosion by water. The steeper and the longer the slope, the higher is the rate of erosion by water because of the greater accumulation of runoff (Wischmeier and Smith 1978; Abate 2011; Alexakis et al. 2013; Tadesse and Abebe 2014). In this study, the slope length (Eq. 3) and slope steepness (Eq. 4) factors were used to calculate and map the LS-factor (Fig. 5d) as has been applied by other studies such as Bewket and Teferi (2009) and Kamaludin et al. (2013). The slope length and steepness values were drawn from the ASTER GDEM $(30 \mathrm{~m}$ resolution) using the ArcGIS Spatial analyst tool and the Arc Hydro tool.

$$
\begin{aligned}
& L=(F A * \text { cell size } / 22.1)^{m} \\
& S=\left(0.065+0.045 S+0.0065 S^{2}\right)
\end{aligned}
$$




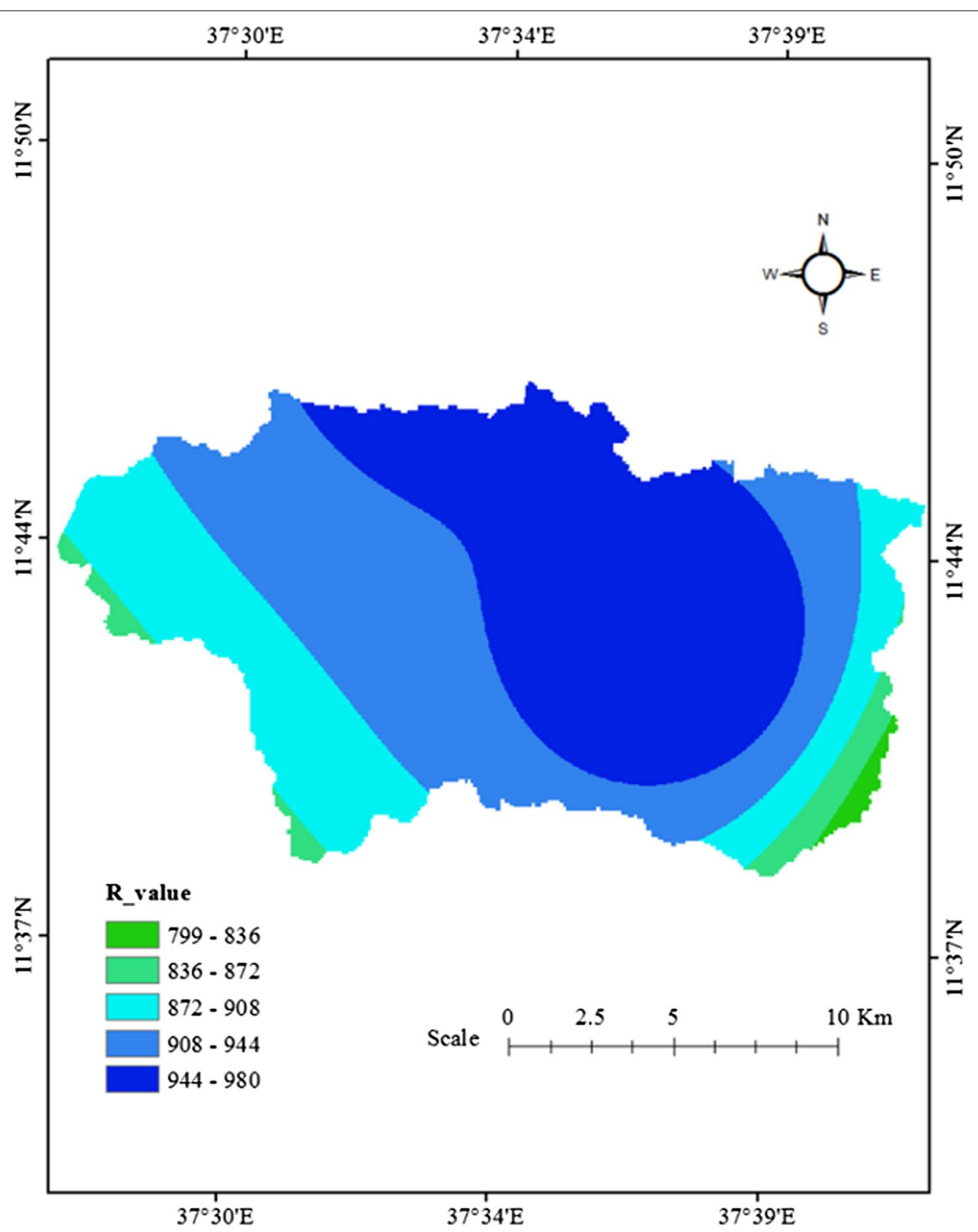

Fig. 3 R-factor map of the Geleda watershed

Table 2 Soil types, coverage and K value based on Hurni (1985), Hellden (1987) and SCRP (1996)

\begin{tabular}{llllrr}
\hline No. & Soil types & Soil colour & Soil erodibility (K value) & Area (ha) & Percent (\%) \\
\hline 1 & Chromic Luvisols & Brown/reddish brown & 0.20 & 8258.67 & 32.25 \\
2 & Eutric Leptosols & Brown to yellowish brown & 0.20 & 848.79 & 3.31 \\
3 & Haplic Luvisols & Brown/reddish brown & 0.20 & 700.74 & 2.74 \\
4 & Luvic Calcisols & Red & 0.25 & $15,802.47$ & 61.7 \\
\hline
\end{tabular}




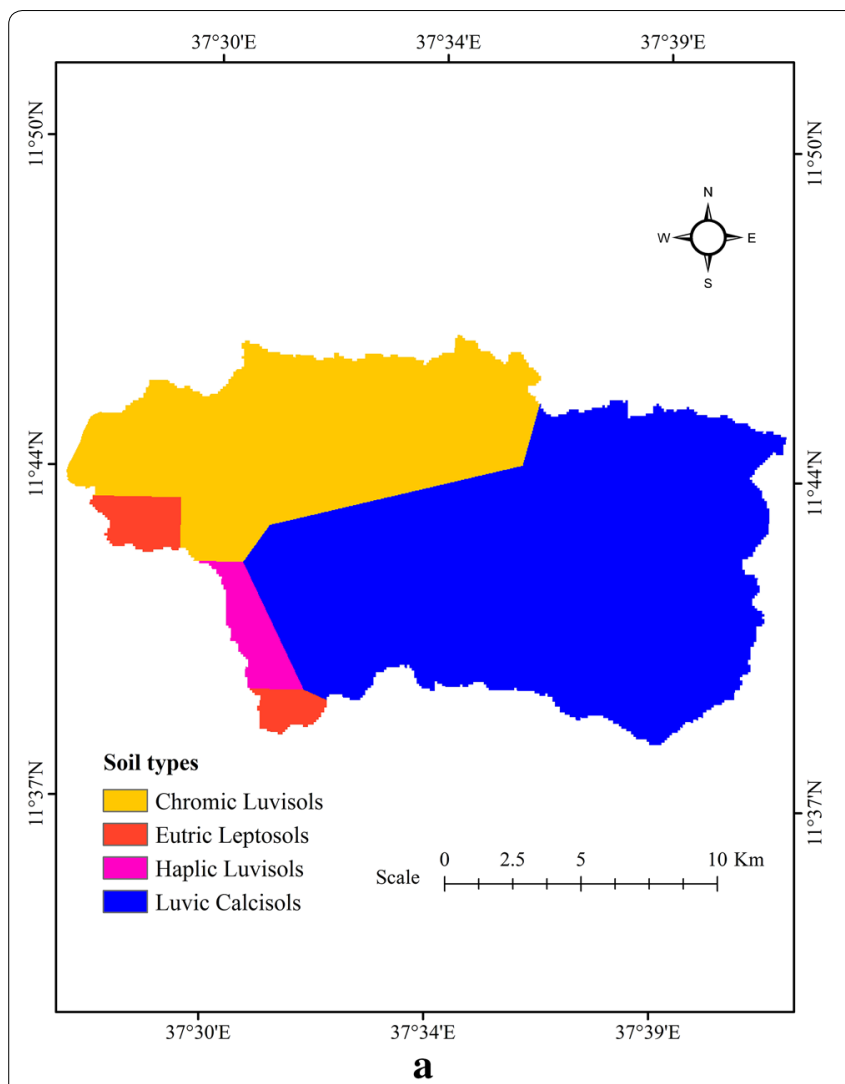

Fig. 4 Soil types (a) and K-factor map (b) of the Geleda watershed

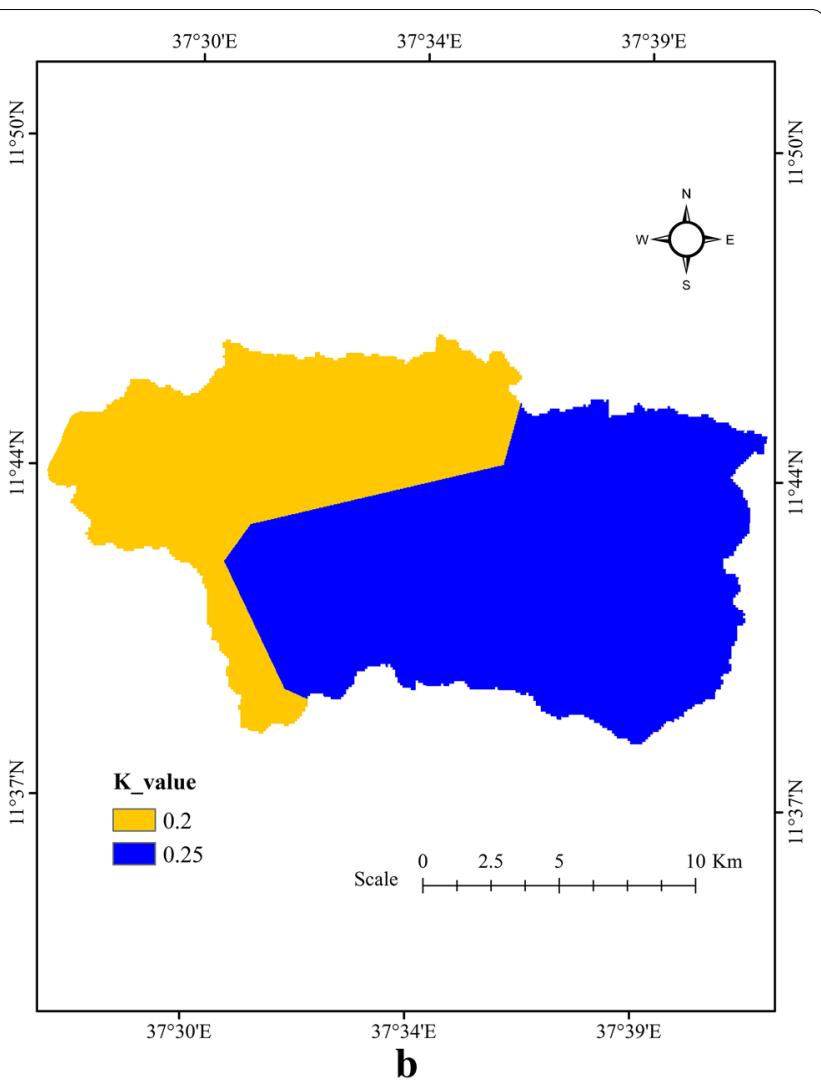

$$
L S=(F A * \text { cell size } / 22.1)^{m} *\left(0.065+0.045 S+0.0065 S^{2}\right)
$$

where $F A$ is flow accumulation, cell size is the resolution of the grid (i.e., $30 \mathrm{~m}$ ), $m$ is an exponent that depends on slope steepness and $S$ is slope gradient in percent.

To run the equation, mapping of $m$ was undertaken by classifying the slope of the watershed according to the $m$ values presented in Table 3 . The resulting $m$ map (Fig. 5a) indicated that values of $m$ vary from 0.2 in the western part of the watershed (lower part of the watershed) to 0.5 in the eastern part of the watershed (head stream of the watershed).

The resulting slope length $(L)$ map indicated that the slope length varied from 0 to 102 (Fig. 5b). The slope steepness $(S)$ map showed that the slope gradient ranged from 0.07 to 2.46 in the lower and head stream of the watershed, respectively (Fig. 5c). Values for the combined $L S$-factor varied between 0 and 28.19 (Fig. 5d).

\section{Cropping and land-cover (C) factor}

The Cropping and land-cover $(\mathrm{C})$ factor represents the ratio of soil loss from land covered by vegetation to the corresponding loss from continuous fallow (Wischmeier and Smith 1978; Morgan 2005). The C-factor is perhaps the most important factor in RUSLE model due to its representation to reduce soil erosion (McCool et al. 1995). For this study, Landsat-8 OLI_TIRS 2015 acquired on 20 February, 2015 (path 170/row 052) was used for producing the land cover map. The image was downloaded from Global Land Cover Facility (GLCF) archive, which has $30 \mathrm{~m}$ resolution and its cloud cover is 0 . In classifying the image, preprocessing tasks such as geometric and radiometric corrections were applied. Image classification was undertaken using both unsupervised and supervised image classification techniques. First preliminary unsupervised classification technique was applied to have an overview on the number of classes present in the watershed. Then, supervised classification with maximum likelihood classification algorism was done by taking 20 ground truth points from five land covers. The land covers are cultivated land, forest, shrub land, grassland and built-up areas (Fig. 6). The classified image has an overall accuracy of $82.8 \%$ with a Kappa coefficient of 0.78. For image processing, ERDAS Imagine 9.3 software was used. For each land cover type, the corresponding $C$ 

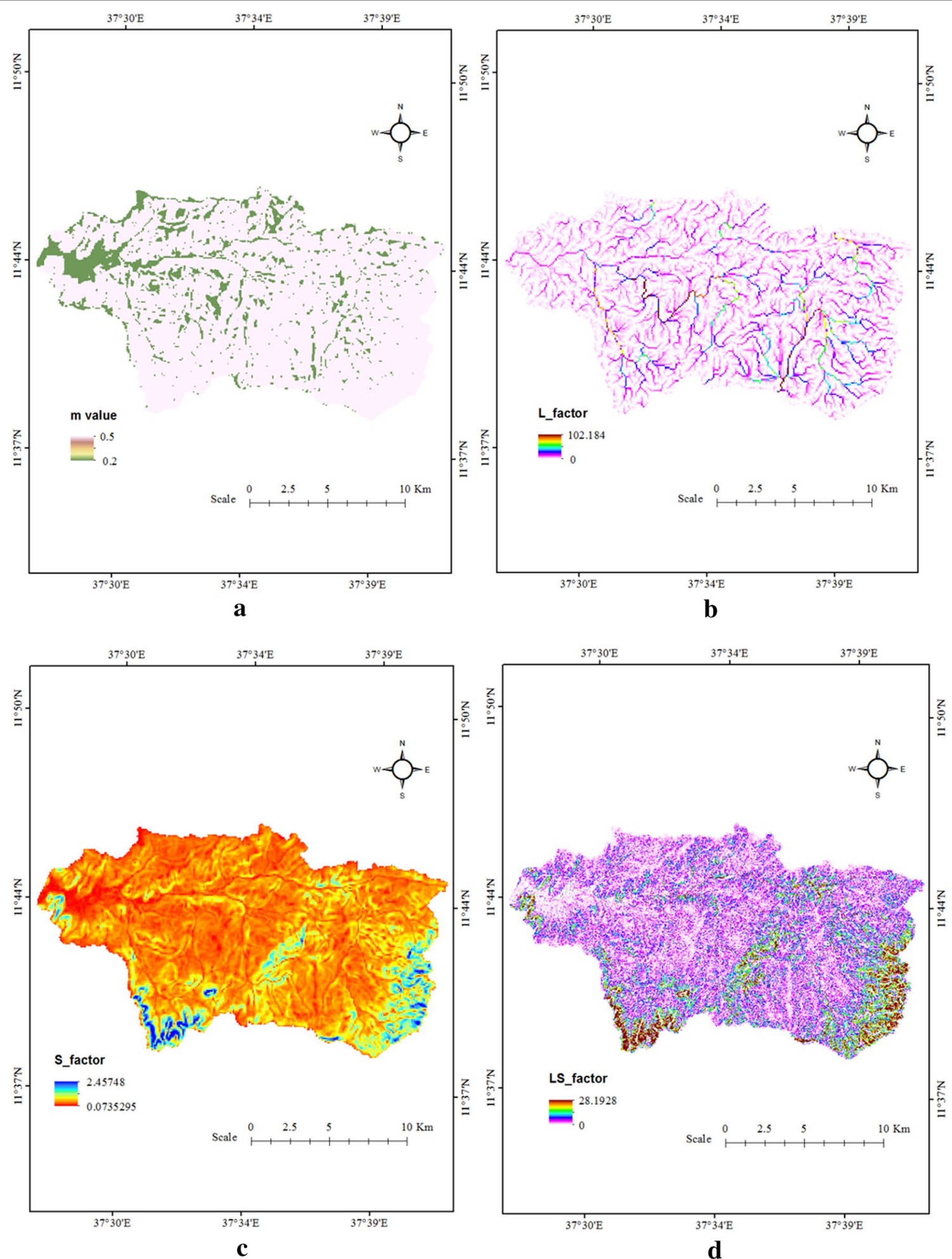

Fig. 5 The $m(\mathbf{a})$, L-factor $(\mathbf{b})$, S-factor (c), and LS-factor (d) maps of Geleda watershed 
Table $3 \mathrm{~m}$ Values for the different slope classes (Wischmeier and Smith 1978)

\begin{tabular}{ll}
\hline Slope class (in percent) & m value \\
\hline$<1$ & 0.2 \\
$1-3$ & 0.3 \\
$3-5$ & 0.4 \\
$>5$ & 0.5 \\
\hline
\end{tabular}

values were assigned using the values suggested and used in different studies (Table 4).

\section{Conservation practice $(P)$ factor}

The conservation practice $(\mathrm{P})$ factor or also known as erosion control practice factor is the ratio of soil loss with a specific conservation practice like contouring, strip-cropping, or terracing measures to the corresponding loss with up and down slope cultivation (Wischmeier and Smith 1978). Thus, the P-factor for RUSLE can be mapped through by collecting data from frequent field observations (Bewket and Teferi 2009; Tadesse and Abebe 2014). However, in our studied area, there were only few conservation measures such as soil and stone bunds, which have been constructed in the past few years. The constructed soil and water conservation structures were poorly maintained. Since there is no complete data on the conservation structures, the P-factor for this study was determined using an alternative method that utilizes slope (Fig. 7) and land cover (Fig. 6) data as suggested by Wischmeier and Smith (1978). This method has also been applied in other similar studies (Bewket and Teferi 2009; Abate 2011; Gelagay and Minale 2016). This method categorizes the land cover into agricultural land and other land covers. Thus, forest, shrub, grassland and built-up areas are considered into other land covers. For other land covers a $P$ value of 1 was assigned regardless of their slope. However, $\mathrm{P}$ value for agriculture land was given with respect to its slope (Table 5). The established $\mathrm{P}$ value was changed into raster map with a cell size of $30 \mathrm{~m}$ (Figs. 7, 8).

\section{Results and discussion}

Rate of soil erosion and severity in the Geleda watershed

The mean annual soil erosion rates ranged from $0 \mathrm{t} \mathrm{ha}^{-1}$ year $^{-1}$ in plain areas to $237 \mathrm{t} \mathrm{ha}^{-1}$ year $^{-1}$ in the hilly terrains of the watershed (Fig. 9). The result shows that the entire watershed looses a total of about 0.16

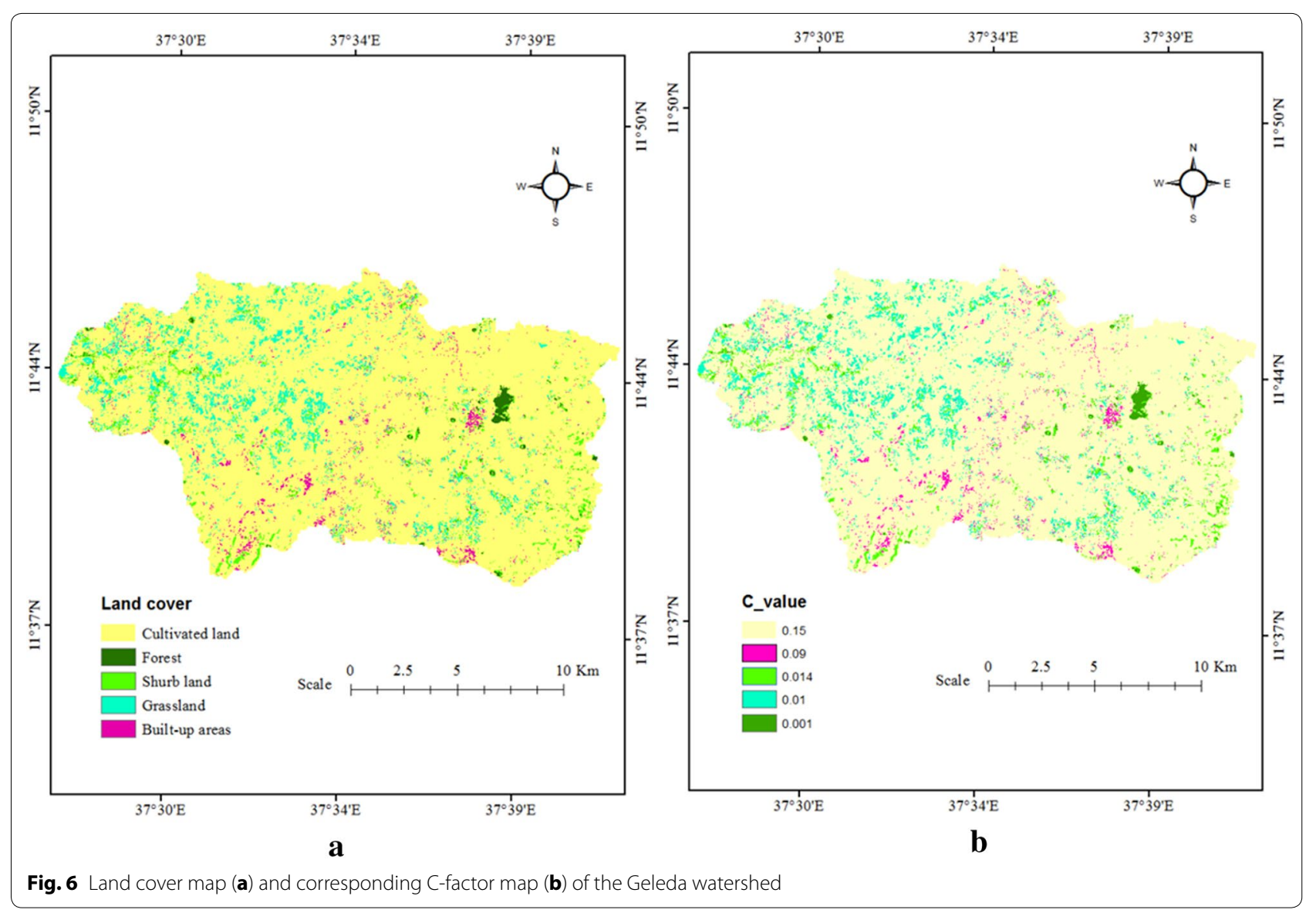


Table 4 Land cover classes and their distribution and C values for the Geleda watershed

\begin{tabular}{lcll}
\hline Land cover & Area (ha) & C value & References \\
\hline Cultivated land & 22,816 & 0.15 & Hurni (1985); Bewket and Teferi (2009); Tadesse and Abebe (2014) \\
Forest & 186 & 0.001 & Hurni (1985); Reusing et al. (2000); Morgan (2005) \\
Shrub land & 778 & 0.014 & Wischmeier and Smith (1978); Abate (2011); Gelagay and Minale (2016) \\
Grassland & 1471 & 0.01 & Hurni (1985); Morgan (2005); Bewket and Teferi (2009); Abate (2011); Tadesse and Abebe (2014) \\
Built-up areas & 358 & 0.09 & Ganasri and Ramesh (2015) \\
Total & 25,609 & & \\
\hline
\end{tabular}

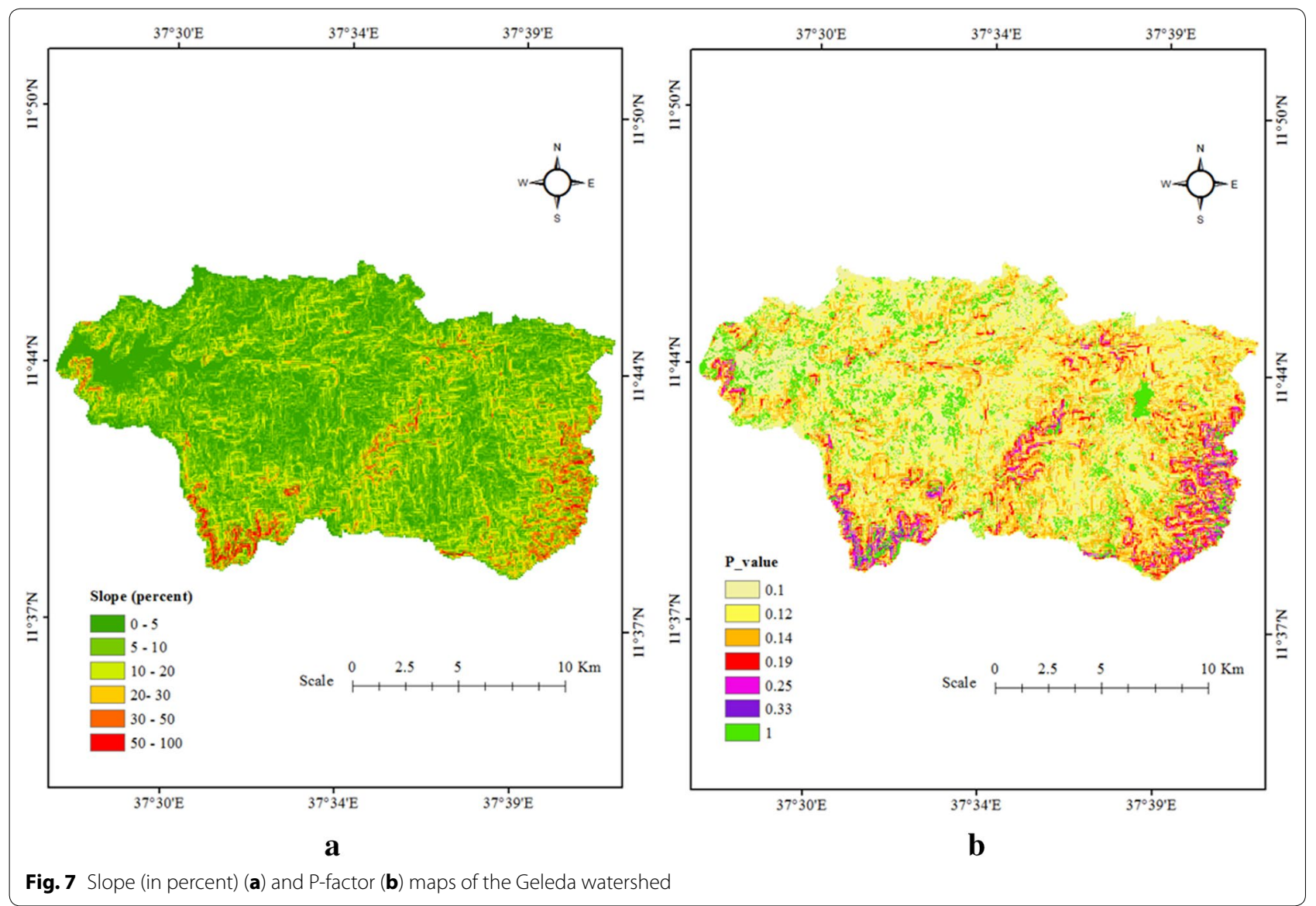

Table 5 P values suggested by Wischmeier and Smith (1978), which were used in the Geleda watershed for the different slope classes of agricultural land

\begin{tabular}{lll}
\hline Land use & Slope (percent) & P value \\
\hline Agricultural land & $0-5$ & 0.1 \\
& $5-10$ & 0.12 \\
$10-20$ & 0.14 \\
& $20-30$ & 0.19 \\
& $30-50$ & 0.25 \\
Other land & $50-100$ & 0.33 \\
\hline
\end{tabular}

million tones of soil annually. In terms of exposure to the risk of erosion, which were set with the Authors consideration, about $78.75 \%$ of the watershed is characterized low soil erosion rate, which is $0-11 \mathrm{t} \mathrm{ha}^{-1}$ year $^{-1}$ and such areas can be considered low risk areas. The remaining areas are categorized as moderate risk areas (13.93\%) with a rate of $11-18 \mathrm{t} \mathrm{ha}^{-1}$ year $^{-1}$, high risk areas (2.76\%) with a rate of $18-30 \mathrm{t} \mathrm{ha}^{-1}$ year $^{-1}$, very high risk areas (3.73\%) with a rate of 30-50 $\mathrm{t} \mathrm{ha}^{-1}$ year $^{-1}$ and severely affected areas $(0.83 \%)$ with a rate of $50-237 \mathrm{t} \mathrm{ha}^{-1}$ year $^{-1}$ (Table 6). The average soil loss rate estimated for the entire watershed was $23.7 \mathrm{t} \mathrm{ha}^{-1}$ year $^{-1}$, which is 


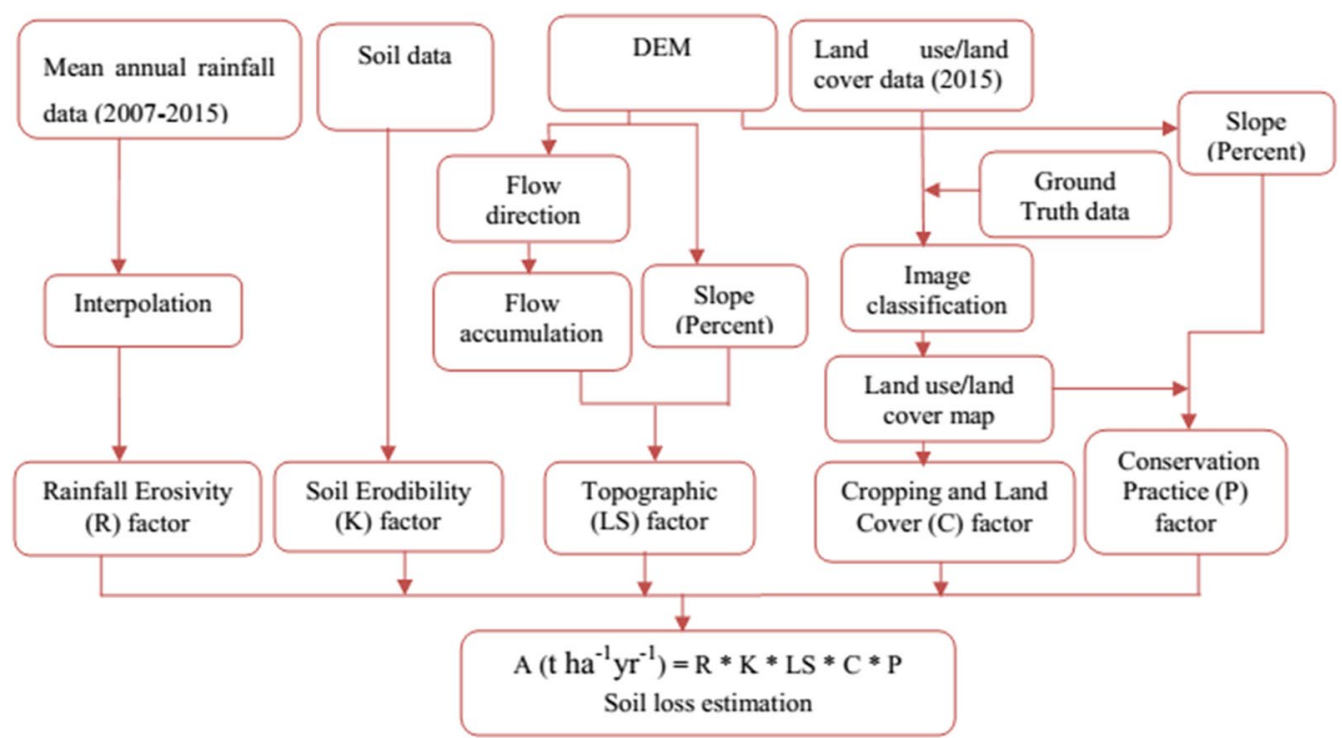

Fig. 8 Summary of methods employed to estimate soil loss by RUSLE model

comparable to the average soil loss rate reported by Hurni (1985) for the highlands $\left(18 \mathrm{t} \mathrm{ha}^{-1}\right.$ year $\left.^{-1}\right)$. The current result also agrees with similar findings reported in Amare et al. (2014) for the Wondo Genet watershed in the eastern highlands $\left(26 \mathrm{t} \mathrm{ha}^{-1} \mathrm{yr}^{-1}\right)$ and in Tadesse and Abebe (2014) for the Jabi Tehinan watershed in the northwestern highlands $\left(30.4 \mathrm{t} \mathrm{ha}^{-1}\right.$ year $\left.^{-1}\right)$. Unlike our findings, some studies however, reported a rather high rate of erosion in different parts of the highlands. For instance, FAO (1986) reported an average soil erosion rate of $35 \mathrm{t} \mathrm{ha}^{-1}$ year $^{-1}$ for the central and northern highlands, Bewket and Teferi (2009) reported an average soil erosion rate of $93 \mathrm{t} \mathrm{ha}^{-1}$ year $^{-1}$ in Chemoga watershed of the Blue Nile basin in the northwestern highlands. In a recent study by Gelagay and Minale (2016) in Koga watershed of the Blue Nile basin reported an average soil erosion rate of $47.4 \mathrm{t} \mathrm{ha}^{-1}$ year $^{-1}$. Reusing et al. (2000) pointed out that about $50 \%$ of the Lake Tana basin is exposed to high to very high risk of soil erosion rates, in some cases reaching as high as $256 \mathrm{t} \mathrm{ha}^{-1}$ year $^{-1}$. A similar assessment has been reported by Gete (2000) in northwestern highlands and reported a very high rate of erosion ranging from 130 to $170 \mathrm{t} \mathrm{ha}^{-1}$ year $^{-1}$. A study by Kebede et al. (2015) in the central rift valley watershed reported a relatively high rate of soil erosion well over $45 \mathrm{t} \mathrm{ha}^{-1}$ year $^{-1}$. The relatively low average soil erosion rate estimated in the current studied watershed could be resulted from the topography, which is largely gentle slope to undulating plains (slope less than 12\%), which accounted $59 \%$ of the watershed. Contrary to the current and other studies in the highlands, few other studies reported very low average soil erosion rate, for instance in
Medego watershed in the northern highlands with a rate of $9.63 \mathrm{t} \mathrm{ha}^{-1}$ year $^{-1}$ by Gebreyesus and Kirubel (2009) and in Zingin watershed with a rate of $9.10 \mathrm{t} \mathrm{ha}^{-1}$ year $^{-1}$ by Gizachew (2015). These results were recorded due to the gentle slope feature of the watersheds. For example, about $49.77 \%$ of Medego watershed is covered with a slope less than $15 \%$.

In the Geleda watershed of the current study, high soil erosion rates were recorded in the steeper slope areas of the watershed (Fig. 9). The slope ranges from 30 to $100 \%$ and the land use is cultivated agricultural land. High erosion rates on steep slopes were also reported in other similar studies such as in Medego watershed where the slope ranged between 30 and 50\% (Gebreyesus and Kirubel 2009) and in Abate (2011) reported erosion rate of more than $80 \mathrm{t} \mathrm{ha}^{-1}$ year $^{-1}$ on steep slope areas in the Borena watershed.

\section{Prioritization for soil conservation planning}

Because of resource limitations, implementing soil conservation measures in the entire watershed at a time is impractical. Thus, prioritization of intervention areas based on the severity and risks of soil erosion is imperative. Hence, based on the estimated rates of erosion, the Geleda watershed is classified and ranked into five priority classes as shown in Table 6 and Fig. 10. The total area that experienced soil erosion rate above the maximum tolerable erosion limit of $11 \mathrm{t} \mathrm{ha}^{-1}$ year $^{-1}$ (Renard et al. 1996) is 5440 ha, which covers $21.25 \%$ of the entire watershed. However, this area accounts for $29.35 \%$ of the total soil loss amounting to $46,092.5$ tons. It can be observed from the assigned classes that the different 


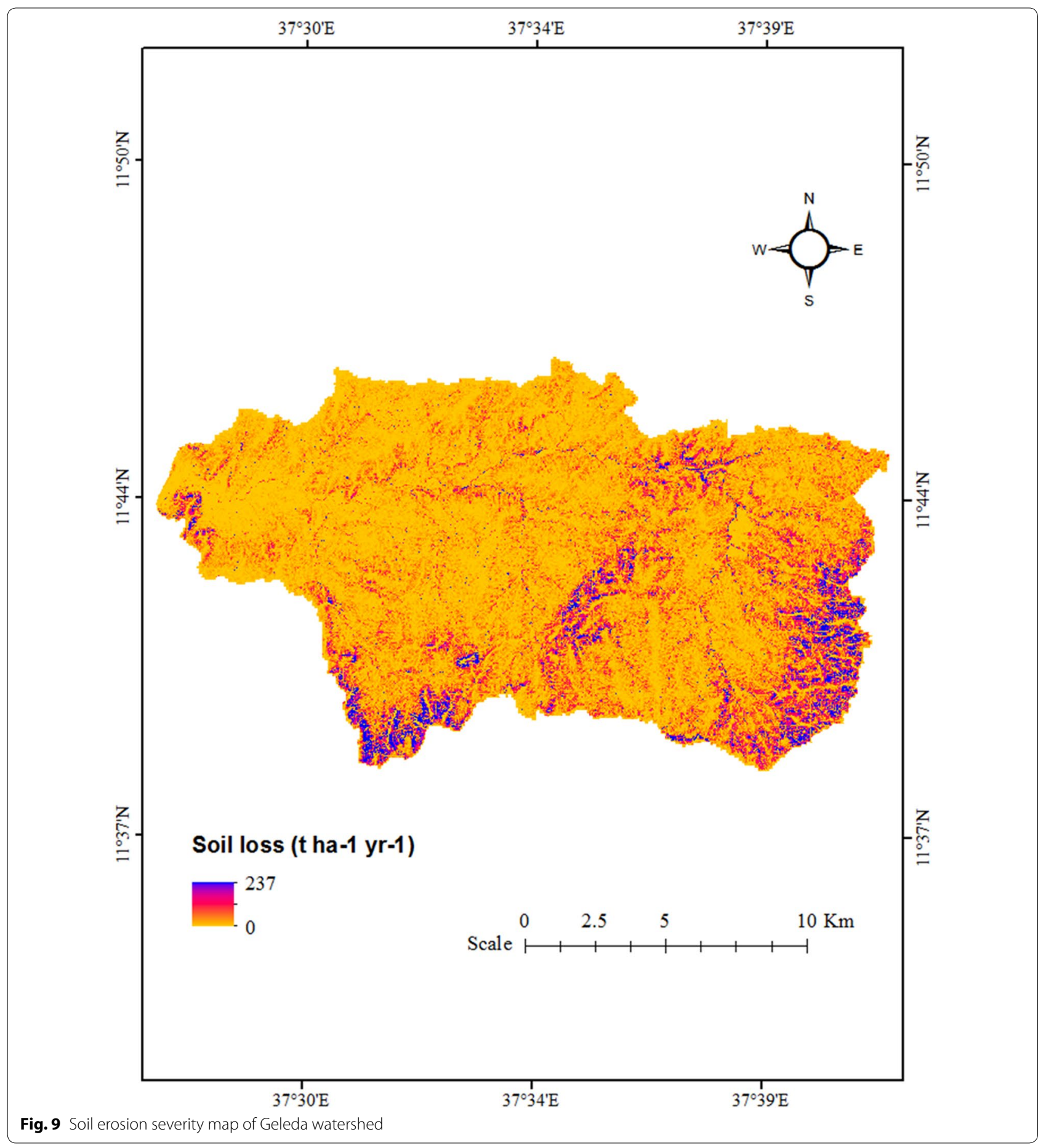

priority areas contributed differently to the total erosion rate. For instance, priority class I covers only $0.83 \%$ of the entire watershed but it accounts about $12.62 \%$ of the total soil loss, which amounts to 19,822 tones. Whereas priority classes II and III combined cover about $6.49 \%$ of the watershed but contributed only $8.78 \%$ of the soil loss amounting to 13,786 tones. Similar with the findings of this study, there are studies which indicated small area of the watershed contributed for the significant amount of soil loss. For example, areas experienced from very high to extremely severe soil loss in Borena watershed accounted $29.85 \%$ but these areas contributed $60.03 \%$ of 
Table 6 Annual soil loss rates and severity classes with their conservation priority in the Geleda watershed

\begin{tabular}{lllrllc}
\hline Soil loss $\left(\mathbf{t ~ h a}^{\mathbf{- 1}} \mathbf{y}^{\mathbf{- 1}}\right)$ & Severity class & Priority classes & Area (ha) & $\begin{array}{l}\text { Percent of total } \\
\text { area }\end{array}$ & $\begin{array}{l}\text { Annual soil loss } \\
\text { (tone) }\end{array}$ & $\begin{array}{l}\text { Percent of total } \\
\text { annual soil loss }\end{array}$ \\
\hline $0-11$ & Low & V & 20,169 & 78.75 & $110,929.5$ & 70.65 \\
$11-18$ & Moderate & IV & 3567 & 13.93 & $12,484.5$ & 7.95 \\
$18-30$ & High & III & 706 & 2.76 & 4236 & 2.70 \\
$30-50$ & Very high & II & 955 & 3.73 & 9550 & 6.08 \\
$50-237$ & Severe & I & 212 & 0.83 & 19,822 & 12.62 \\
\hline
\end{tabular}

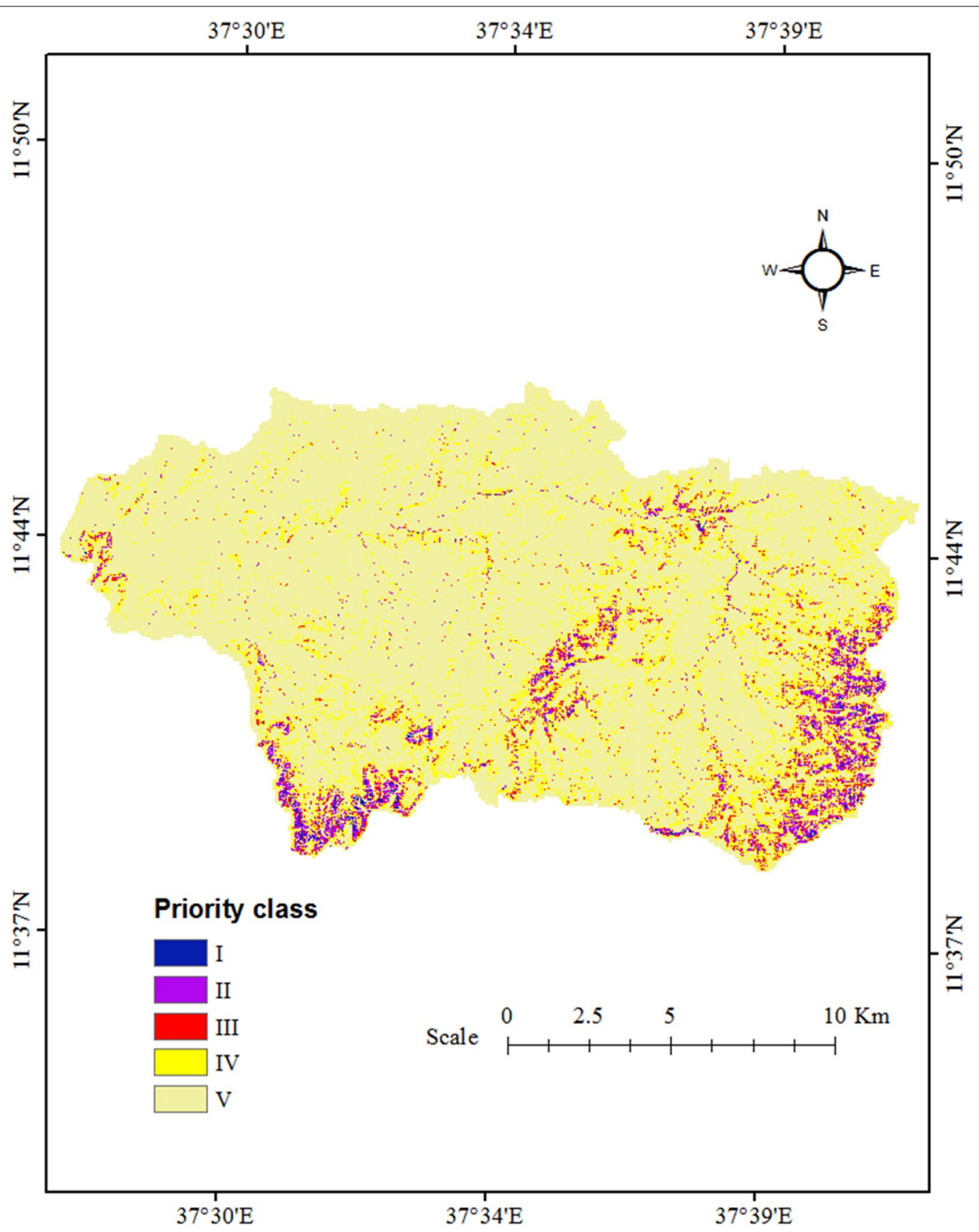

Fig. 10 Prioritization map for soil conservation planning 
the soil loss estimated in the studied watershed (Abate 2011). In Wondo Genet watershed also $54.54 \%$ of the soil loss was contributed from $23.5 \%$ of the watershed (Amare et al. 2014). On the other hand, in priority class $\mathrm{V}$ the amount of soil loss is a bit larger. Even though these areas contributed $70.65 \%$ of total annual soil loss, the rate of soil loss is below the acceptable soil loss range. Therefore, undertaking soil conservation measures based on the given priority is a better option as also suggested by Bewket and Teferi (2009), Abate (2011), Amare et al. (2014) and Gizachew (2015) for their respective study sites.

\section{Conclusion}

Soil erosion is a serious problem in the steep areas of the watershed, which extends up to $237 \mathrm{t} \mathrm{ha}^{-1}$ year $^{-1}$. The extensions of cultivated land resulted in high soil losses in these areas. Since resources limitations didn't allow for implementing soil conservation measures at a time, the entire watershed was arranged into 5 priority areas. Hence, undertaking soil conservation measures based on the given priority is desirable. The developed model can be used in similar watersheds for erosion risk assessment, planning and subsequent prioritizations of conservation measures in erosion susceptible areas of the Ethiopian highlands.

\section{Abbreviations \\ DEM: digital elevation model; GIS: geographic information system; GPS: global positioning system; IDW: inverse distance weight; OLI_TIRS: operational land imager-thermal infrared sensor; RUSLE: Revised Universal Soil Loss Equation; USLE: Universal Soil Loss Equation.}

\section{Authors' contributions}

TG: carried out designing the research idea, method design, field data collection, data analysis and interpretation, prepare draft of the manuscript, and structuring the report; TT: participated in method design, data analysis and interpretation, and structuring the report; MA participated in method design, data analysis and interpretation, and structuring the report. All authors read and approved the final manuscript.

\section{Authors' information}

Temesgen Gashaw is a Ph.D. candidate in Environmental Science at Addis Ababa University and lecturer at department of Natural Resource Management in Adigrat University. He has given watershed management, land degradation and rehabilitation, land use planning, and GIS and remote sensing courses, and also published more than 15 articles in the internationally peer reviewed journals.

Taffa Tulu is a professor of Hydrology and Watershed Management in Addis Ababa University in Center of Environment and Development under College of Development Studies. He has authored five books and more than 40 publications. His spheres of professional expertise are Agricultural Engineering; Land Improvement and Water Management; Hydrology; and Irrigation and Water Engineering.

Mekuria Argaw (Ph.D.) is associate professor of Environmental Science at the College of Natural Science in Addis Ababa University. He specializes in Ecology and Natural Resources Management. He teaches courses on watershed management and land degradation. Dr. Mekuria has published several peer reviewed papers on soil erosion, land degradation, biodiversity, watershed processes and climate change impacts.

\begin{abstract}
Author details
${ }^{1}$ Center for Environmental Science, College of Natural Sciences, Addis Ababa University, Addis Ababa, Ethiopia. ${ }^{2}$ Center for Environment and Development, College of Development Studies, Addis Ababa University, Addis Ababa, Ethiopia. ${ }^{3}$ Department of Natural Resource Management, College of Agriculture and Environmental Science, Adigrat University, Adigrat, Ethiopia.
\end{abstract}

\section{Acknowledgements}

The Authors greatly acknowledge Center for Environmental Science, Addis Ababa University for financial support; Amhara National Regional State Bureau of Finance and Economic Development (ANRS BoFED) for providing soil data; Ethiopian Metrological Agency for providing metrological data and Dera Woreda agricultural office for transport facility during field work. We would also like to express our deepest gratitude to the two anonymous reviewers for their valuable comments.

\section{Competing interests}

The authors declare that they have no competing interests.

Received: 6 July 2016 Accepted: 15 December 2016

Published online: 06 January 2017

\section{References}

Abate S (2011) Estimating soil loss rates for soil conservation planning in the Borena woreda of South Wollo highlands, Ethiopia. J Sustain Dev Afr 13(3):87-106

Ag Water Solutions (2012) Watershed management in Ethiopia. Agricultural water management learning and discussion brief

Alexakis D, Hadjimitsis D, Agapiou A (2013) Integrated use of remote sensing, GIS and precipitation data for the assessment of soil erosion rate in the catchment area of "Yialias" in Cyprus. Atmos Res 131:108-124

Alkharabsheh M, Alexandridis T, Bilas G, Misopolinos N, Silleos N (2013) Impact of land cover change on soil erosion hazard in northern Jordan using remote sensing and GIS. Procedia Environ Sci 19:912-921

Amare S, Nega C, Zenebe G, Goitom T, Alemayoh T (2014) Landscape-scale soil erosion modeling and risk mapping of mountainous areas in eastern escarpment of Wondo Genet watershed, Ethiopia. Int Res J Agric Sci Soil Sci 4(6):107-116

Angima S, Stott D, O'Neill M, Ong C, Weesies G (2003) Soil erosion prediction using RUSLE for central Kenyan highland conditions. Agr Ecosyst Environ 97:295-308

Bekele S, Holden ST (1998) Resource degradation and adoption of land conservation technologies in the Ethiopian Highlands: a case study in Andit Tid, North Shewa, Ethiopia. Agric Econ 18:233-247

Bewket W, Teferi E (2009) Assessment of soil erosion hazard and prioritization for treatment at the watershed level: case study in the Chemoga watershed, Blue Nile basin, Ethiopia. Land Degrad Dev 20:609-622

BlancoCanqui H, Lal R (2008) Principles of soil conservation and management. Springer Science + Business Media B.V, Berlin, p 240

Derege T, Atsushi T, Mitsuru T, Nigussie H (2012) Dynamics and hotspots of soil erosion and management scenarios of the Central Rift Valley of Ethiopia. Int J Sed Res 27:84-99

Desta L, Carucci V, Wendem-Ageňehu A, Yitayew A (eds) (2005) Community based participatory watershed development: A guideline. Ministry of Agriculture and Rural Development, Addis Ababa, p 62

Eaton D (1996) The economics of soil erosion: A model of farm decision-making. Discussion Papers 24134. International Institute for Environment and Development. Environmental Economics Programme, p 48

EFAP (Ethiopian Forestry Action Program) (1993) Ethiopian Forestry Action Program: the challenge for development, vol 2. Ministry of Natural Resources Development and Environmental Protection, Addis Ababa

FAO (1986) Ethiopian highlands reclamation study, Ethiopia. Final Report. Rome, FAO

Ganasri BP, Ramesh H (2015) Assessment of soil erosion by RUSLE model using remote sensing and GIS—a case study of Nethravathi Basin. Geosci Front. doi:10.1016/j.gsf.2015.10.007 
Gebreyesus B, Kirubel M (2009) Estimating soil loss using Universal Soil Loss Equation (USLE) for soil conservation planning at Medego Watershed, Northern Ethiopia. J Am Sci 5(1):58-69

Gelagay HS, Minale AS (2016) Soil loss estimation using GIS and Remote sensing techniques: a case of Koga watershed, Northwestern Ethiopia. Int Soil Water Conserv. doi:10.1016/j.iswcr.2016.01.002i

Gete Z (2000) Landscape dynamics and soil erosion process modeling in the North-Western Ethiopian highlands. African Studies Series A16. Geographica Bernensia, Berne

Gete Z (2006) Integrated management of watershed experiences in Eastern and Central Africa: Lessons from Ethiopia. In: Shiferaw B and Rao KPC (eds): Integrated management of watersheds for agricultural diversification and sustainable livelihoods in Eastern and Central Africa: lessons and experiences from semi arid South Asia. Proceedings of the international workshop held at ICRIS at Nairobi, 6-7 December 2004, p 120

Gizachew A (2015) A geographic information system based soil loss and sediment estimation in Zingin watershed for conservation planning, Highlands of Ethiopia. World Appl Sci J 33(1):69-79

Hailu K, Klik A (2015) Predicting the spatial distribution of soil erodibility factor using USLE nomograph in an agricultural watershed, Ethiopia. Int Soil Water Conserv Res 3:282-290

Hellden U (1987) An assessment of woody biomass, community forests, land use and soil erosion in Ethiopia: a feasibility study on the use of remote sensing and GIS analysis for planning purposes in developing countries. Lund University Press, Lund

Hurni H (1985) Erosion-productivity-conservation systems in Ethiopia. In: Proceedings of paper presented at the 4th international conference on soil conservation, Maracay, Venezuela

Hurni H (1988) Degradation and conservation of the resources in the Ethiopian Highlands. Mt Res Dev 8:123-130

Hurni H (1993) Land degradation, famine, and land resource scenarios in Ethiopia. In: Pimentel D (ed) World soil erosion and conservation. Cambridge University Press, Cambridge, pp 27-62

Hurni $\mathrm{H}$ (2002) Current international actions for furthering the sustainability use of soils. Symposium paper no. 63 on 17th WCSS, 14-21 August 2002, p 8

Kamaludin H, Lihan T, Rahman Z, Mustapha M, Idris W, Rahim S (2013) Integration of remote sensing, RUSLE and GIS to model potential soil loss and sediment yield (SY). Hydrol Earth Syst Sci Discuss 10:4567-4596

Kebede W, Habitamu T, Efrem G, Fantaw Y (2015) Soil erosion risk assessment in the Chaleleka wetland watershed, Central rift valley of Ethiopia. Environ Syst Res 4(5):1-12

Lal R (2001) Soil degradation by erosion. Land Degrad Dev 12:519-539

McCool DK, Foster GR, Renard KG, Yoder DC, Weesies GA (1995) The revised universal soil loss equation. Department of Defense/Interagency workshop on Technologies to address soil erosion on Department of Defense Lands San Antonio, TX, June 11-15, 1995, p 9

Menale K, Mahmud Y, Köhlin G (2009) The role of production risk in sustainable land-management technology adoption in the Ethiopian Highlands. Working papers in economics, No 407. Gothenburg: University of Gothenburg, p 25

Ministry of Agriculture and Rural Development (MoARD) (2010) Ethiopia's Agricultural Sector Policy and Investment Framework (PIF) 2010-2020. Draft Final Report, p 39
Moore ID, Wilson JP (1992) Length-slope factors for the revised universal soil loss equation: simplified method of estimation. J Soil Water Conserv 47(5):423-428

Morgan RPC (2005) Soil erosion and conservation, 3rd edn. Blackwell Science, Oxford

Nigussie H, Ademnur B, Atsushi T, Mitsuru T, Derege T (2012) Integrated watershed management as an effective approach to curb land degradation: a case study of the Enabered watershed in northern Ethiopia. Environ Manage 50:1219-1233

Nyssen J, Poesen J, Moeyersons J, Deckers J, Mitiku H, Lang A (2004) Human impact on the environment in the Ethiopian and Eritrean Highlands: a state of the art. Earth Sci Rev 64(3-4):273-320

Oldeman L, Van Lynden G, Van Engelen V (1995) An international methodology for soil degradation assessment and for a soils and terrain digital database (SOTER). Paper presented at the regional workshop on assessment and monitoring of land degradation, Cairo, May 13-15, 1995

Prasannakumar V, Vijith H, Abinod S, Geetha N (2012) Estimation of soil erosion risk within a small mountainous sub-watershed in Kerala, India, using Revised Universal Soil Loss Equation (RUSLE) and geo-information technology. Geosci Front 3(2):209-215

Renard KG, Foster GR, Weesies GA, McCool DK, Yoder DC (1996) Predicting soil erosion by water: a guide to conservation planning with the Revised Universal Soil Loss Equation (RUSLE). United States Department of Agriculture, Handbook No. 703, p 384

Renard KG, Foster GR, Weesies GA, Porter JP (1997) RUSLE: Revised Universal Soil Loss Equation. J Soil Water Conserv 46(1):30-33

Reusing M, Schneider T, Ammer U (2000) Modeling soil loss rates in the Ethiopian highlands by integration of high resolution MOMS-02/D2-stereodata in a GIS. Int J Remote Sensing 21(9):1885-1896

Soil Conservation Research Project (SCRP) (1996) Soil erosion hazard assessment for land evaluation. Research report. SCRP, Addis Ababa

Sonneveld B, Keyzer M (2003) Land under pressure: soil conservation concerns and opportunities for Ethiopia. Land Degrad Dev 14:5-23

Taddese G (2001) Land degradation: a challenge to Ethiopia. Environ Manage 27:815-824

Tadesse A, Abebe M (2014) GIS based soil loss estimation using RUSLE Model: the case of Jabi Tehinan Woreda, ANRS. Ethiopia. Natural Resour 5:616-626

Terranova O, Antronico L, Coscarelli R, laquinta P (2009) Soil erosion risk scenarios in the Mediterranean environment using RUSLE and GIS: an application model for Calabria (Southern Italy). Geomorphology 112:228-245

Tongul H, Hobson M (2013) Scaling up an integrated watershed management approach through social protection programmes in Ethiopia: the MERET and PSNP schemes

Wischmeier WH, Smith DD (1978) Predicting rainfall erosion losses: a guide to conservation planning. United States Department of Agriculture, Handbook No. 537, p 58

\section{Submit your manuscript to a SpringerOpen ${ }^{\circ}$ journal and benefit from:}

- Convenient online submission

- Rigorous peer review

- Immediate publication on acceptance

- Open access: articles freely available online

- High visibility within the field

- Retaining the copyright to your article

Submit your next manuscript at $\boldsymbol{\nabla}$ springeropen.com 